\title{
Artificial teeth: evaluation of wear resistance, microhardness and composition
}

\author{
Dentes artificiais: avaliação da resistência ao desgaste, microdureza e composição
}

Matheus GRANDO'

Lívia Muniz PACHECO'

Daniela Maffei BOTEGA'

Luciana Mayumi HIRAKATA²

Juliana Balbinot HILGERT ${ }^{1}$

\section{ABSTRACT}

\section{Objective}

To evaluate the Knoop hardness, composition, and wear resistance of acrylic-resin artificial teeth exposed to mechanical toothbrushing

\section{Methods}

Artificial teeth from three commercial brands - Biotone, Trilux, and Soluut PX - were used. From each brand, 10 teeth were selected for wear evaluation after mechanical brushing, 10 for microhardness testing, and 5 for composition analysis. Specimens underwent 55,000 brushing cycles, under a 200-g load and at a frequency of 250 cycles per minute, using a soft-bristled toothbrush (IndicatorPlus 30, Oral-B) soaked in a 1:1 toothpaste/water slurry (Oral B Pró Saúde). Microhardness testing was performed using a 25-g load for 15 seconds in an HMV-2 hardness tester (Shimadzu). The composition of teeth from different brands was determined by scanning electron microscopy with energy-dispersive $X$-ray spectroscopy (SEMIEDS) (Jeol JSM 5800).

\section{Results}

Wear results after mechanical brushing were compared by means of the paired t-test, whereas those obtained in microhardness testing were compared by ANOVA with Bonferroni correction. There was no statistically significant difference between brands in either trial.

\section{Conclusion}

Composition analysis revealed that all of the artificial teeth analyzed contain carbon and oxygen. Trilux and Soluut PX brand teeth also contain silicon; however, the presence of filler particles did not result in increased resistance.

Indexing terms: Acrylic resins. Artificial teeth. Hardness.

\section{RESUMO}

\section{Objetivo}

Avaliar a microdureza Knoop, composição e resistência ao desgaste de dentes artificiais de resina acrílica submetidos ao ensaio de escovação mecânica.

\section{Métodos}

Foram selecionados 10 dentes para o ensaio de escovação mecânica, 10 para microdureza e 5 para determinação da composição, de três marcas comerciais: Biotone, Trilux e Soluut PX. As amostras foram submetidas a 55.000 ciclos de escovação, sob carga de $200 \mathrm{~g}$ e frequência de 250 ciclos por minuto, utilizando escova dental macia (IndicatorPlus 30, Oral-b), imersas em solução de dentifrício/água destilada na proporção de 1:1(Oral B Pró Saúde). O ensaio de microdureza foi realizado sob carga de 25 gramas durante 15 segundos em microdurômetro (HMV-2, Shimadzu). A composição das diferentes marcas comerciais foi determinada em MEV 5800, utilizando EDS que permite a análise química por meio de raios-x.

\section{Resultados}

Os resultados obtidos no ensaio de escovação mecânica foram submetidos ao teste $t$ pareado e aqueles obtidos no ensaio de microdureza Knoop foram submetidos à Análise de Variância e teste de BONFERRONI. Não houve diferença estatisticamente significativa entre as marcas em ambos os ensaios.

\section{Conclusão}

A análise da composição revelou que todos os dentes artificiais possuem carbono e oxigênio. Os dentes das marcas Trilux e Soluut PX apresentam também silício em sua composição, entretanto, a presença de partículas de carga não resultou em aumento da resistência.

Termos de indexação: Resinas acrílicas. Dente Artificial. Dureza.

\footnotetext{
${ }^{1}$ Universidade Federal do Rio Grande do Sul, Faculdade de Odontologia. Rua Ramiro Barcelos, 2492, Santa Cecilia, Porto Alegre, RS 90035-004, Brasil. Correspondência para / Correspondence to: DM BOTEGA. E-mail: <danimaffei@yahoo.com>.

${ }^{2}$ Pontifícia Universidade Católica do Rio Grande do Sul, Faculdade de Odontologia, Departamento de Prótese. Porto Alegre, RS, Brasil.
} 


\section{INTRODUCTION}

Progressively lower rates of tooth loss are considered a long-term trend, due to advances in the area of oral health, particularly in the prevention and treatment of dental caries and periodontal disease ${ }^{1}$. Nevertheless, as life expectancy increases, the demand for prosthodontic rehabilitation will continue to exist ${ }^{2-4}$.

Since 1940, acrylic resin has been used in the manufacturing of artificial teeth for prosthetic rehabilitation with complete and removable partial dentures ${ }^{5-6}$. These teeth are widely used due to their ease of handling, possibility of characterization, glossy surface after polishing, adequate color stability, easy fit, and good esthetic outcome $\mathrm{e}^{7-10}$. However, major concerns exist regarding their wear resistance and ability to maintain a stable occlusal relationship over time ${ }^{11-13}$. Wear secondary to daily use may lead to changes in the vertical dimension of occlusion, decreased masticatory efficiency, loss of esthetics, and discomfort, as well as potential temporomandibular joint disorders, thus interfering with patient quality of life².

Wear resistance can be assessed by combining tests such as mechanical toothbrushing, abrasion between teeth and different materials, composition analysis, chewing simulators, and structural microhardness testing 12,14-18. Mechanical toothbrushing with toothpaste plays an important role in artificial tooth surface wear, as, in addition to the effects of bristle friction on the material, the abrasive compounds present in the majority of toothpaste formulations may potentiate abrasion wear on the surface ${ }^{19-20}$.

Microhardness testing is used for classification of materials and as a parameter for comparative analysis of changes in material properties. Among the various methods available, Vickers hardness testing and Knoop hardness testing are those most widely used in dentistry ${ }^{21-22}$.

Many studies have reported attempts by manufacturers to improve the properties of acrylic-resin artificial teeth by addition of various substances to the material11,17-18,23 with a view to improving wear resistance and, consequently, increasing the longevity of dental prosthetics and reducing the negative effects of material wear.

Some studies have shown the superiority of certain brands in terms of wear resistance ${ }^{11}$; others have found no correlation between chemical composition and wear resistance ${ }^{12}$. When evaluating the wear resistance of artificial teeth, determining the chemical composition of the sampled material is important to ascertain whether higher concentrations of a given chemical element in the acrylic resin formulation could have a positive or negative effect on resistance.

The objective of the present study was to evaluate the wear of artificial teeth from different manufacturers after mechanical toothbrushing and whether wear correlates with microhardness test results and composition analysis findings.

\section{METHODS}

Three commercial brands of artificial teeth commonly used in the fabrication of removable dental prostheses were selected for this study. The materials used in the study are listed in Table 1.

Table 1. Material, brand, and manufacturers.

\begin{tabular}{|c|c|c|}
\hline Material & Brand & Manufacturer \\
\hline $\begin{array}{l}\text { Artificial } \\
\text { tooth }\end{array}$ & Biotone & $\begin{array}{l}\text { Dentsply Indústria e Comércio } \\
\text { Ltda., Petrópolis, RJ, Brazil }\end{array}$ \\
\hline $\begin{array}{l}\text { Artificial } \\
\text { tooth }\end{array}$ & TRILUX & $\begin{array}{l}\text { VIPI Indústria, Comércio, } \\
\text { Exportação e Importação de } \\
\text { Produtos Odontológicos Ltda., } \\
\text { Pirassununga, SP, Brazil }\end{array}$ \\
\hline $\begin{array}{l}\text { Artificial } \\
\text { tooth }\end{array}$ & Soluut PX & $\begin{array}{c}\text { Kotalmports, São Paulo, SP, } \\
\text { Brazil }\end{array}$ \\
\hline Toothbrush & $\begin{array}{l}\text { Indicator Plus 30, } \\
\text { soft-bristled }\end{array}$ & $\begin{array}{l}\text { Oral-B, Procter \& Gamble do } \\
\text { Brasil S.A., Manaus, AM, Brazil }\end{array}$ \\
\hline Toothpaste & Oral-B Pro-saúde & $\begin{array}{l}\text { Oral-B, Procter \& Gamble do } \\
\text { Brasil S.A. Queimados, RJ, Brazil }\end{array}$ \\
\hline
\end{tabular}

\section{Specimen fabrication}

Each specimen consisted of an artificial tooth (maxillary canine) fixed to a 54 × 24 × 5-mm self-curing acrylic resin base (Jet Incolor, Artigos Odontológicos Clássico Ltda., Campo Limpo Paulista, SP, Brazil). A total of 30 specimens were fabricated, 10 from each brand.

Using a metal cutting disc (KG Sorensen, Medical Burs Ltda., São Paulo, SP, Brazil), two cuts were made on the buccal surface of the tooth: one vertical and one horizontal, on the midportion of the tooth and $2 \mathrm{~mm}$ below the incisal region respectively. This was done to provide a reference landmark to assess tooth structure reduction due to wear after the mechanical brushing test. Four measurements were obtained from each specimen before and after testing, and the arithmetic mean of these measurements was considered for analysis. Measurements were obtained with Mitutoyo calipers precise to $0.01 \mathrm{~mm}$ (Mitutoyo Sul Americana, São Paulo, SP, Brazil). 


\section{Mechanical toothbrushing test}

Specimens were placed in clear acrylic containers $(54 \times 24 \times 50 \mathrm{~mm}$ ) into which a toothpaste (Oral B Pró Saúde) slurry made from $6 \mathrm{~g}$ toothpaste dissolved in 6 $\mathrm{ml}$ water was poured until specimens were completely submerged ${ }^{24-25}$. These containers were then placed on a mechanical toothbrushing machine by means of reference pins on the base of the machine (Figures 1 and 2).

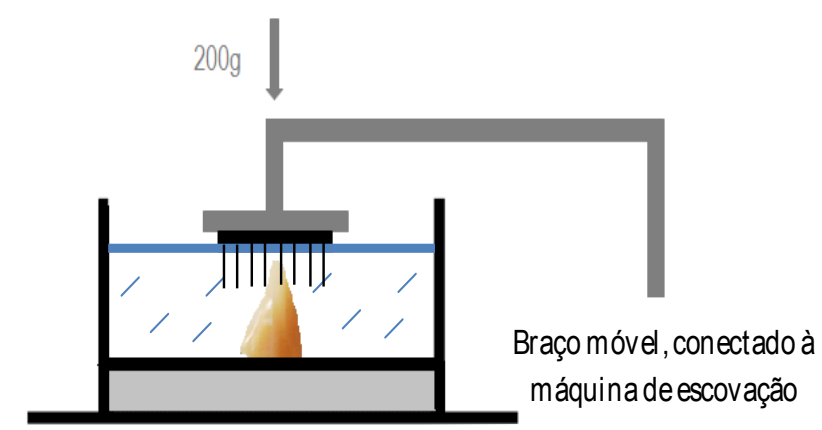

Figure 1. Toothbrush in position above a specimen submerged in toothpaste slurry.

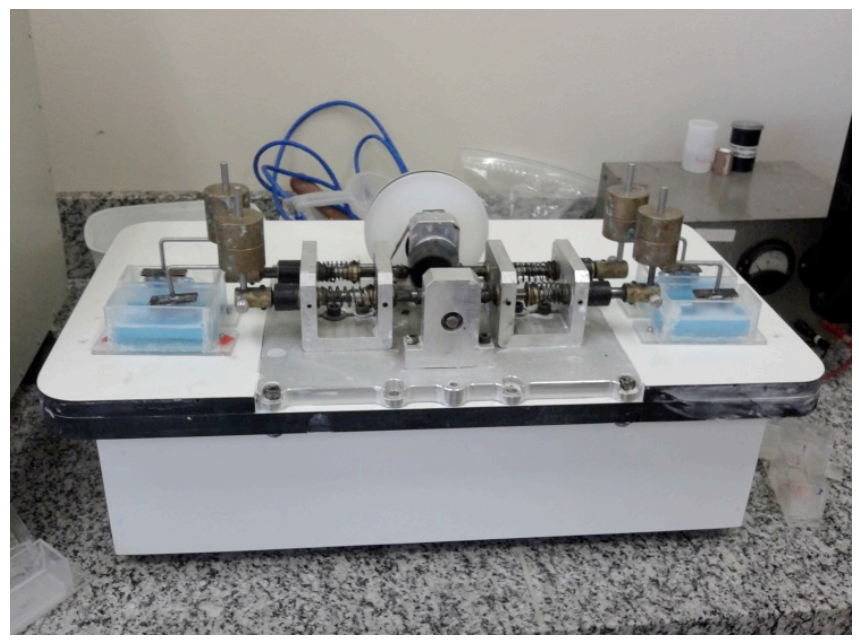

Figure 2. Containers placed on the mechanical toothbrushing machine.

The mechanical toothbrushing machin (Indicator Plus 30, Oral-B) machine used in this study was designed specifically for abrasion testing, set to a $200 \mathrm{~g}$ load, 12 $\mathrm{mm}$ horizontal displacement, and a frequency of 250 cycles per minute ${ }^{26-27}$. All toothbrushes used were softbristled. The active part of each toothbrush was cut off and bonded to the moving upper arm of the machine with cyanoacrylate adhesive (Super-Bonder, Loctite, Itapevi, SP, Brazil). Toothbrush bristles were positioned over the incisal surface of the tooth so as to ensure contact between the two during the alternating motions of the machine. The machine performed 55,000 brushing cycles, to simulate 5 years of denture use, taking into account thrice-daily tooth brushing. Brushes and toothpaste slurry were replaced every 5,000 cycles, representing approximately 6 months of use ${ }^{26}$.

\section{Knoop hardness testing}

For microhardness testing, 10 cylindrical specimens (diameter $\sim 3.5 \mathrm{~cm}$, height $1.5 \mathrm{~cm}$ ) were fabricated for each artificial tooth brand.

The artificial teeth were embedded in self-curing acrylic resin. First, the selected canines were placed onto a glass table with the buccal aspect facing down and set in place using utility wax. Metal cylinders lubricated with petroleum jelly were used as molds. Each cylinder was placed atop the artificial tooth so that the tooth remained centered with the circumference of the mold. Self-curing acrylic resin, manipulated in accordance with manufacturer instructions, was then poured into each cylinder. After the resin had set, specimens were removed from the cylinders. A model trimmer was then used to wear down the surface of each specimen that had faced the glass surface, thus exposing the central portion of the tooth and obtaining a flat surface. Microhardness testing requires an extremely polished surface; therefore, the specimens were polished with increasingly fine grits of silicon carbide paper (600 through 1200) in a metallographic polishing machine (Arotec-APL 4, Arotec AS Ind. Com., Cotia, SP, Brazil), followed by application of Poligloss TDV resin polishing compound (Dental Ltda., Pomerode, SC, Brazil) to the exposed portion of the tooth with a felt wheel.

A Shimadzu HMV-2T hardness tester was used for Knoop hardness measurement. Briefly, five indentations were made in a random pattern on the central region of each tooth.

Knoop hardness was measured by a software program connected to the hardness tester, measuring only the long diagonal of the indentation left on the sample by the pyramidal diamond penetrator. A 25-g load was used, applied for 15 seconds.

\section{Chemical composition analysis}

Identification of the chemical elements present in artificial teeth from each of the selected manufacturers was performed using a scanning electron microscope (JEOL JSM 5800). This system has an electron probe micro-analyzer with EDS (energy-dispersive X-ray spectroscopy) capabilities and a simple backscatter device that also enables $\mathrm{X}$-ray chemical analysis. These resources allow identification of elements from 
boron to uranium that are present in the sample at a concentration above $2 \%$.

Before observation, specimens were cleaned by submerging in $99.9 \%$ ethanol and sonicating for 30 minutes. After this procedure, specimens were removed from the ultrasonic bath using tongs, dried, sputter-coated with gold, and stored in a plastic container. There was no further contact with the samples until completion of observations. Five unbrushed artificial teeth from each group were selected at random for this test.

The present study was blinded, as each of the assessment groups and each specimen within each group were identified only by numbers, assigned by the academic advisor of the project, which did not allow the examiners to determine group allocation during testing. Furthermore, all examiners were previously calibrated to eliminate the possibility of bias at the time of interpretation of the results of the mechanical brushing test. To this end, both examiners obtained measurements from teeth used during pilot testing, and the means of these measurements were compared until equality was achieved.

The paired t-test was used to compare pre- and post-assay values obtained from the mechanical brushing test for each brand, whereas analysis of variance (ANOVA) with Bonferroni's method was applied to the mean values obtained from microhardness testing.

\section{RESULTS}

Toothbrushing test: There were no statistically significant differences between baseline and post-assay vertical wear values in any of the tested brands, as shown in Table 2 (Biotone, $p=1.00$; Trilux, $p=0.316$; Soluut PX, $\mathrm{p}=0.338$, paired $t$-test).

Table 2. Comparison between mean wear values (standard deviations) before and after the mechanical toothbrushing test $(\mathrm{mm})$

\begin{tabular}{ccc}
\hline & Pre-experiment & Post-experiment \\
\hline Mean $( \pm$ SD $)$ & Mean $( \pm$ SD $)$ \\
\hline Biotone & $2.05( \pm 0.13) \mathrm{a}$ & $2.05( \pm 0.14) \mathrm{a}$ \\
Trilux & $2.45( \pm 0.21) \mathrm{b}$ & $2.43( \pm 0.21) \mathrm{b}$ \\
Soluut & $2.29( \pm 0.37) \mathrm{c}$ & $2.22( \pm 0.22) \mathrm{c}$ \\
\hline
\end{tabular}

Knoop hardness: There were no statistically significant differences in mean microhardness across the three tested brands of artificial teeth on analysis of variance (ANOVA), as shown in Table 3 (same lowercase letter after means denotes no statistically significant difference, Bonferroni's method).
Table 3. Means and standard deviations of Knoop hardness values.

\begin{tabular}{ll}
\hline & Mean $( \pm$ SD $)$ \\
\hline Biotone & $20.53( \pm 0.71)$ a \\
Trilux & $20.13( \pm 1.20)$ a \\
Soluut & $20.31( \pm 0.82)$ a \\
\hline
\end{tabular}

Scanning electron microscopy analysis: All tested brands contained the elements carbon (C) and oxygen (O). Teeth from the Trilux and Soluut PX brands also contained the element silicon (Si), as shown in Table 4. The values represent the mean of 5 specimens from each brand.

Table 4. Mean percent content of major chemical components.

\begin{tabular}{lccc}
\hline Specimen & C (\%) & O (\%) & Si (\%) \\
\hline Biotone & 66.22 & 0.74 & - \\
Trilux & 98.23 & 0.02 & 41.55 \\
Soluut PX & 52.80 & 1.09 & 0.68 \\
\hline
\end{tabular}

As the results show, the concentration of each chemical element varies widely across the tested brands. Other elements that are not part of the chemical composition of artificial teeth were also found, including aluminum (Al), rubidium ( $\mathrm{Rb})$, niobium $(\mathrm{Nb})$, bromine $(\mathrm{Br})$, and fluorine (F). This finding may simply be an artifact, as the excitation energy of these elements is similar to that of the actual components of artificial teeth. The presence of gold $(\mathrm{Au})$ is the result of the sputter coating process, which is necessary for SEM testing. Depending on the film thickness (usually $20 \mathrm{~nm}$ ) and the density of the specimen material, the element may be detected. Therefore, the detection of these elements is considered a bias inherent to the testing method and should be disregarded when discussing results.

\section{DISCUSSION}

The advent of acrylic resin brought about a revolution in dentistry, due to the major advantages of this material, including ease of handling, better adhesion to denture bases, and lower fracture susceptibility as compared with ceramics ${ }^{16}$. Despite these ample advantages, acrylic teeth have little wear resistance. Therefore, manufacturers sought to overcome this issue by adding substances to the composition of artificial teeth in an attempt to improve this important mechanical property, on which maintenance of the vertical dimension of occlusion - and, consequently, a stable, adequate occlusion - depends ${ }^{12,22}$. 
The results of the present study showed that no statistically significant vertical wear occurred within each brand group before and after the brushing test. All teeth were equally resistant to the vertical wear caused by a mechanical brushing test designed to simulate 5 years' worth of thrice-daily tooth brushing.

Khan et al. ${ }^{28}$ conducted a similar study in which they compared different brands of artificial teeth and also found no differences whatsoever in wear resistance.

Manly et al. ${ }^{29}$ showed that artificial brushing is more vigorous, and can be more abrasive, than manual brushing, which leads to differences between laboratory tests and in vivo reality. However, the credibility of laboratory simulations of toothbrushing is supported by the literature, that demonstrated similarity between laboratory results and clinical experiments ${ }^{11}$.

The various brands of artificial teeth available on the market have substantially different purchase prices, as was the case with the teeth tested in the present study. According to public information provided by the manufacturers, Biotone teeth contain an "interpenetrating polymer network". Trilux teeth are claimed to have "double crosslinking" and "organically modified ceramics", whereas Soluut PX teeth are claimed to contain a "composite resin". All manufacturers justify the addition of these substances by claiming they would increase wear resistance. In view of these claims, the initial hypothesis of the present study was that Soluut PX brand teeth would exhibit the greatest resistance to vertical wear, given the addition of a composite resin to its formulation. However, there were no statistically significant differences among any of the tested brands, which demonstrates that addition of the aforementioned substances does not affect the resistance of acrylic teeth.

In the present study, the mechanical resistance of the specimen materials was also evaluated by Knoop hardness testing. Again, the results showed no statistically significant differences in mean values across the three tested brands of artificial teeth.

The addition of inorganic filler particles (quartz, colloidal silica, or particulate glass) is essentially meant to improve the mechanical properties of resins by reducing their organic matrix content, thus minimizing disadvantages such as curing shrinkage, a high linear thermal expansion coefficient, and water sorption ${ }^{30}$.

As noted above, the presence of a composite resin (i.e., filler particles) in Soluut PX brand artificial teeth suggested that specimens of this brand would be more resistant and, therefore, exhibit higher microhardness values. However, hardness testing showed that addition of filler particles did not improve this mechanical property. The same reasoning applies to Trilux brand teeth, which contain silica. The results of the present study may be compared to those of Loyaga-Rendom et al. ${ }^{15}$, who found no statistically significant differences in Vickers hardness across different commercial brands of artificial teeth with and without filler elements in their composition.

According to Anusavice ${ }^{21}$, acrylic-resin artificial teeth are composed essentially of carbon (C), oxygen (O), and hydrogen $(\mathrm{H})$. It is also known that the manufacturer claims of addition of "organically modified ceramics" and "composite resin" to Trilux and Soluut PX brand teeth, respectively, refer to the element silicon (Si). Therefore, SEM analysis was focused on these elements, with the purpose of ascertaining their relative contribution to the composition of artificial teeth from the tested brands. (Hydrogen is not detectable by this method of analysis.)

The results showed that all artificial teeth from all three manufacturers subjected to SEM analysis are composed of carbon and oxygen, with wide variation in the relative content of these elements across different brands. In addition, the Trilux and Soluut PX brand teeth contain silicon ( $\mathrm{Si}$ ) in their compositions, at different concentrations.

As shown in Table 4, Soluut PX teeth, which are claimed by their manufacturer to contain a composite resin, exhibited a lower carbon content than the other brands, and proportionally greater silicon content. However, this was not associated with any difference in microhardness values. Trilux brand teeth had a greater carbon content than those of any other brand, as well as greater homogeneity in carbon content across specimens, and contained less silicon than Soluut PX brand teeth; again, this was not associated with any difference in microhardness. Biotone brand teeth exhibited the greatest heterogeneity in terms of carbon content; nevertheless, as expected, this factor did not reduce their wear resistance or microhardness as compared with the other tested brands.

Further studies are needed to better elucidate the properties of artificial teeth, e.g., the behavior of these teeth during attrition testing.

In clinical practice, artificial teeth are known to undergo marked wear, which leads patients to the dentist in search of replacements. This finding prompted the present study, to ascertain whether different artificial teeth exhibit differences in wear resistance and, thus, define 
which provides the best cost-benefit ratio for the patientin other words, to determine whether using artificial teeth that are more expensive, but have greater longevity, would be advantageous by eliminating the need for early replacement of the prosthetic appliance.

In light of the results of this study, it was conclude that prosthetic wear is not associated with the composition of the artificial teeth, and may instead result from other factors, such as dental attrition, brushing with a hard-bristled toothbrush, submerging the prosthesis in denture cleansing products, and even food consistency. brands o

\section{CONCLUSION}

On the basis of the results of the present study and taking its limitations into account, it was conclude that:

\section{REFERENCES}

1. Siqueira GP, Santos MB, Santos JF, Marchini L. Patients' expectation and satisfaction with removable dental prosthesis therapy and correlation with patients' evaluation of the dentists. Acta Odontol Scand. 2013;71(1):210-4. doi: 10.3109/00016357.2012.654612.

2. Pun DK, Waliszewski MP, Waliszewski KJ, Bersins D. Survey of partial removable dental prosthesis (partial RDP) types in a distinct patient population. J Prosthet Dent. 2011;106(1):48-56. doi:10.1016/S0022-3913(11)60093-0

3. Dhingra K. Oral rehabilitation considerations for partially edentulous periodontal patients. J Prosthodont. 2012;21(6):494513. doi: 10.1111/j.1532-849X.2012.00864.x

4. Aquino ARL, Sousa AS, Carreiro AFP, Germano AR, Mendonça SL, Holanda DVM. Implant-supported removable partial denture. RGO, Rev Gaúch Odontol. 2013;61(1):127-32.

5. Barbosa DB, Barão VA, Monteiro DR, Compagnoni MA, Marra J. Bond strength of denture teeth to acrylic resin: effect of thermocycling and polymerisation methods. Gerodontology. 2008;25(4):237-44. doi: 10.1111/j.17412358.2008.00218.x

6. Freire TS, Aguilar FG, Garcia LF, Pires-de-Souza FC. Colour stability of denture teeth submitted to different cleaning protocols and acceleratedartificial aging. Eur J Prosthodont Restor Dent. 2014;22(1):24-7.

7. Marra J, Souza RF, Barbosa DB, Pero AC, Compagnoni MA. Evaluation of the bond strength of denture base resins to acrylic resin teeth: effect of thermocycling. J Prosthodont. 2009;18(5):438-43. doi: 10.1111/j.1532849X.2009.00478.x

8. Arana-Correa BE, Sepúlveda-Navarro WF, Florez FL, Urban VM, Jorge JH, Campanha NH. Colour stability of acrylic resin denture the three brands of acrylic-resin artificial teeth tested did not exhibit statistically significant differences in resistance to vertical wear from toothbrushing or in Knoop hardness; the artificial teeth tested differ in terms of their percent content of the elements carbon and oxygen; and that the Trilux and Soluut PX brand teeth also contain the element silicon, but this difference in composition did not provide additional resistance.

\section{Collaborators}

M GRANDO, LM PACHECO, and DM BOTEGA designed the proposed method and participated in manuscript writing. LM HIRAKATA guided and monitored use of the mechanical brushing machine and participated in manuscript writing. JB HILGERT performed statistical analysis and participated in manuscript writing.

teeth after immersion in different beverages. Eur J Prosthodont Restor Dent. 2014;22(2):56-61.

9. Gregorius WC, Kattadiyil MT, Goodacre CJ, Roggenkamp CL, Powers JM, Paravina RD. Effects of ageing and staining on color of acrylic resin denture teeth. J Dent. 2012;40(Suppl 2):e47-54. doi: 10.1016/j.jdent.2012.09.009

10. Suwannaroop $P$, Chaijareenont $P$, Koottathape N, Takahashi $\mathrm{H}$, Arksornnukit $\mathrm{M}$. In vitro wear resistance, hardness and elastic modulus of artificial denture teeth. Dent Mater J. 2011;30(4):461-8. doi: 10.4012/dmj.2010-200

11. Hirano S, May KB, Wagner WC, Hacker $\mathrm{CH}$. In vitro wear of resin denture teeth. J Prosthet Dent. 1998;79(2):152-5. doi: 10.1016/ S0022-3913(98)70209-4

12. Stober $T$, Lutz $T$, Gilde $H$, Rammelsberg P. Wear of resin denture teeth by two-body contact. Dent Mater. 2006;22(3):243-9. doi: 10.1016/j.dental.2005.03.009

13. Shetty MS, Shenoy KK. An in vitro analysis of wear resistance of commercially available acrylic denture teeth. J Indian Prosthodont Soc. 2010;10(3):149-53. doi: 10.1007/s13191-010-0023-z.

14. Zeng J, Sato Y, Ohkubo C, Hosoi T. In vitro wear resistance of three types of composite resin denture teeth. J Prosthet Dent. 2005;94(5):453-7. doi: 10.1016/j.prosdent.2005.08.010

15. Loyaga-Rendom PG, Takahashi H, Hayakawa I, Iwasaki N. Compositional characteristics and hardness of acrylic and composite resin of artificial teeth. J Prosthet Dent. 2007;98(2):141-9. doi: 10.1016/S0022-3913(07)60047-X

16. Ghazal $M$, Steiner $M$, Kern $M$. Wear resistance of artificial denture teeth. Int J Prosthodont. 2008;21(2):166-8.

17. Hahnel S, Behr M, Handel G, Rosentritt M. Two-body wear of artificialacrylic and composite resin teeth in relation to antagonist material. J Prosthet Dent. 2009; 101(4):269-78. doi: 10.1016/S0022-3913(09)60051-2 
18. Stober $T$, Henninger $M$, Schmitter $M$, Pritsch $M$, Rammelsberg P. Three-body wear of resin denture teeth with and without nanofillers. J Prosthet Dent. 2010;103(2):108-17. doi: 10.1016/ S0022-3913(10)60014-5

19. Heintze SD, Forjanic M, Ohmiti K, Rousson V. Surface deterioration of dental materials after simulated toothbrushing in relation to brushingtime and load. Dent.Mater. 2010;26(4):306-19. doi: 10.1016/j.dental.2009.11.152

20. Pisani MX, Pereira EE, Paranhos HFO, Silva CHL. Alteration of the bristles of a toothbrush after brushing of the acrylic resin using different dentifrices. RGO, Rev Gaúch Odontol. 2012;60(4):449-54.

21. Anusavice KJ. Mechanical properties of dental materials. In: Anusavice KJ. Phillips' science of dental materials. 10th ed. Philadelphia: Saunders; 1996. p. 69-71.

22. Vasconcelos LR, Consani RL, Mesquita MF, Sinhoreti MA Effect of chemical and microwave disinfection on the surface microhardness of acrylic resin denture teeth. J Prosthodont. 2013;22(4):298-303. doi: 10.1111/jopr.12009

23. Söderholm KJ. Chemistry of synthetic resins. In: Anusavice KJ. Phillips' science of dental materials. 10th ed. Philadelphia: Saunders; 1996. p. 268-9

24. Lambrechts $P$, Debels $E$, van Landuyt $K$, Peumans $M$, van Meerbeek B. How to simulate wear? Overview of existing methods. Dent Mater. 2006;22(8):693-701. doi: 10.1016/j. dental.2006.02.004
25. Hermann C, Mesquita MF, Consani RL, Henriques GE. The effect of aging by thermal cycling and mechanical brushing on resilient denture liner hardness and roughness. J Prosthodont. 2008;17(4):318-22. doi: 10.1111/j.1532-849X.2007.00293.x

26. Mainieri VC, Beck J, Oshima HM, Hirakata LM, Shinkai RS. Surface changes in denture soft liners with and without coating following abrasion with mechanical brushing. Gerodontology. 2010;28(2):146-51. doi: 10.1111/j.1741-2358.2010.00375.x

27. Trauth KG, Godoi AP, Colucci V, Corona SA, Catirse AB. The influence of mouthrinses and simulated toothbrushing on the surface roughness of a nanofilled composite resin. Braz Oral Res. 2012;26(3):209-14. doi: 10.1590/S1806-83242012000300005

28. Khan Z, Morris JC, von Fraunhofer JA. Wear of anatomic acrylic resin denture teeth. J Prosthet Dent. 1985;53(4):550-1.

29. Manly RS, Wiren J, Manly PJ, Keene RC. A method for measurement of abrasion of dentin by toothbrush and dentifrice. J Dent Res. 1965;44:533-40.

30. Söderholm KJ. Restorative resins. In: Anusavice KJ. Phillips' science of dental materials. $10^{\text {th }}$ ed. Philadelphia: Saunders; 1996. p. 274-82. 
M GRANDO et al. 